\title{
Internationalization in Hungarian higher education. Recent developments and factors of reaching better global visibility ${ }^{* *}$
}

\section{JUDIT LANNERT ${ }^{1^{*}}$ (1) and ANDRÁS DERÉNYI ${ }^{2}$ (1)}

\author{
${ }^{1}$ T-Tudok Knowledge Management and Educational Research Centre, Budapest, Hungary \\ ${ }^{2}$ Hungarian Institute for Educational Research and Development, Budapest, Hungary
}

\section{THEMATIC ARTICLE}

Published online: December 22, 2020

(C) 2020 The Author(s)

\section{ABSTRACT}

Authors present the main results of a research conducted in 2017. Extensive empirical data have been gathered on different issues and dimensions of internationalization among Hungarian universities. Doctoral schools have been covered as well. Data analysis unfolded local and systemic features of internationalization. Hungarian universities are diverse in their development of internationalization. Four development phases of internationalization at institutional level are tackled by mapping internal and external as well as quantitative and qualitative factors. The most advanced universities have reached the point from where a shift could be made from quantitative measures to qualitative ones in order to develop further.

\footnotetext{
*Corresponding author. E-mail: lannert.judit@t-tudok.hu

**An earlier version of the paper was presented at the 4th Central European Higher Education Cooperation (CEHEC) Conference - Higher Education in Central and Eastern Europe: National, Regional and European Trajectories (12-13 April, 2018, Budapest). In this paper the authors present where Hungarian higher education stands in the increasingly intense global process of internationalization and what kind of challenges it must face, by using the information and data of two recently conducted research projects. (The two projects: "International students in the Hungarian higher education institutions" and "Internationalization of doctoral schools in Hungary" was financed by TEMPUS Public Foundation in the framework of EFOP-3.4.2-VEKOP-15-201500001 project).
} 


\section{KEYWORDS}

higher education, academic achievement, educational evaluation, phases of internationalization, international students, programs in foreign languages, student mobility patterns

\section{GLOBAL PROCESSES AND LOCAL DILEMMAS}

When taking stock of the processes and results of internationalization in Hungarian higher education, it is expedient to look at the internationalization processes taking place at different levels. Besides the overarching global scene, in a regional and neighbourhood context, differing attributes of internationalization can be identified (Derényi, 2014), which should be taken into consideration when designing research and also when evaluating findings.

In the global higher educational space there is a growing competition to attract foreign students, and an increasing number of countries are jumping on the bandwagon. The competition is stoked partly by changes in national educational markets. In some countries, the local higher education system is unable to meet the needs, in terms of both quantity and quality, of a significant expansion in higher education despite massive publicly financed developments. As a result, some students have recourse to educational services of other countries, which are becoming more and more readily available. Another group of countries reach out to foreign students, even from the farthest countries of the world, because their local student numbers have been declining, or in an effort to improve the quality of their education, or driven by the need to increase the income of higher educational institutions. As they have an interest in attracting and retaining better trained workforce, governments also stimulate competition in higher education by introducing different regulations and incentives. All this has resulted in a more intensive and diversified export of academic services. At the same time traditional mobility patterns have been changing due to new educational strategies and development-induced interventions by governments, and also because of major changes in the numbers of entrants in tertiary education: East-to-West and South-to-North mobility has been easing and movements in the opposite direction have appeared, especially from the West to the Far East (British Council, 2018). In addition to supporting the traditional trends of student migration new forms of internationalization have been gaining ground. Branch and affiliated campuses (sometimes very far) outside the borders of the country, joint programmes offered with foreign partner institutions, university networks, holdings, associations, and cooperatives, are typical solutions in the AngloSaxon world but recently other regions have followed suit (Knight, 2012). In the Middle East, Far East and Africa some governments are developing favourable conditions by targeted infrastructure developments, tax breaks and support schemes, thus creating an attractive environment for branches and site units of the best foreign universities and research institutes to settle there, and developing higher education, research and innovation hubs. Another trend that started a few years ago is the expansion of virtual training and virtual universities. All this highlights the fact that besides promoting different ways of internationalization, providing educational services locally and internationalizing home campuses has become another major trend (Streitwieser, 2014).

Patterns in the regional scenes can be different from each other and also from the global level. International student mobility continues to be strong in regions encompassing a few 
countries or groups of countries. The choice on offer to international students is often determined by a particular priority field of studies (for instance medicine in Central and Eastern Europe or Cuba), and regional mobility and support schemes shape internationalization (such as the Erasmus + programme in Europe).

National history and special state interest can result in cross-border programmes in neighbouring countries. In many cases the key factors of these programmes are the language of tuition and cultural identity: state measures are driven by the intention to maintain and propagate linguistic and cultural goals and to protect the state's own higher education system. An example is Hungary's higher education policy efforts to provide higher education services in the mother tongue to Hungarians living in neighbouring countries. Conversely, state measures to protect local students' access to the national higher education system from a massive inbound mobility of Slovakian and German youths have been deployed in the Czech Republic and Austria respectively (Brandenburg \& Federkeil, 2013).

The personal profile of international students varies a great deal in terms of the role mobility plays in their ideas about their studies and future careers. Some are involved in shorter mobility to obtain credits and experience; others study for the duration of a full programme and get a degree abroad. Some return to their home country to continue with their studies or careers, relying on the benefits granted by mobility. Others stay in the host country and pursue advanced studies or build a career (Choudara \& de Witt, 2014). Their classification is fraught with problems, which limits the assessment and comparability of student involvement in internationalization. What makes a student 'international' is by no means evident. Looking at it from the angle of nationality, mother tongue or residence, the result can be vastly different (Teichler, Ferencz, \& Wachter, 2011). A young Hungarian citizen who speaks a foreign language better than Hungarian because he lived abroad with his parents posted in a foreign country, and now returns to Hungary to study at a university could be put in different categories depending on the basis of classification. A student who has lived in Hungary for years, is fluent in Hungarian, graduated from a Hungarian grammar school, and is involved in Hungarian higher education but he is not a Hungarian citizen; a non-Hungarian student from the Hungarian-populated areas across the borders, who studies in a Hungarian programme, as Hungarian is his mother tongue; a student who is a Hungarian citizen, lives in Hungary, whose mother tongue is Hungarian and studies in a Hungarian university's programme offered in a foreign language. And so on. These cases also exist in other countries and with other languages, and depending on the answers, the results are different. The individual's perspective is not the same as that of the institution or the state that extends funding or grants, and levies tuition fees based on different considerations. In the case of some of the students mentioned in these examples, academic staff don't even notice that they teach non-Hungarian students in a Hungarian programme, just as they cannot necessarily distinguish Hungarian and foreign citizens in programmes where the language of tuition is other than Hungarian. Continuing along the same lines, another question to be answered is what criteria determine whether Hungarian medical universities' practice of strictly segregating the training of foreign medical students from the Hungarian-language training, or programmes offered in Hungarian to local students together with Hungarianspeaking students from neighbouring countries can be considered as part of the internationalization process.

The answers to the questions raised above can be, and, based on international comparative studies, are different, depending on national and international education policies, institutional 
considerations and research issues (Brandenburg \& Federkeil, 2007). The primary aim of this study is not to resolve these dilemmas; rather, we have taken into account the multifaceted approach when designing the research and evaluating the findings, and segmented the Hungarian data accordingly.

\section{THE RESEARCH AND ITS METHODS}

Where is Hungarian higher education in the globally interpretable internationalization process mentioned above? To answer this question, we are helped by the results of two empirical research projects aimed at revealing the internationalization processes and problems of Hungarian higher education and covering the whole spectrum of higher education in 2017. One research project covered different aspects of internationalization in the first and second cycle programmes. The second project covered the third cycle (doctoral levels) and the doctoral schools. Apart from technical reasons, the separation of the doctoral studies in the research design was justified by the fact that it is a less researched area so far. A separately designed research could focus deeply on doctoral schools' specific approach to internationalization. Although the research aimed at covering internationalization activities in a broad sense, and we examined several dimensions of it, it soon turned out that basically both institutions and decision-makers restrict this area to student mobility; therefore this dimension is preponderant in the study.

Since internationalization of higher education is a dynamically-occurring process around the world, which is why it is not easy to grasp, so different aspects and dimensions have been distinguished for the analysis. Such an important analytical aspect may be that the activity promoting internationalization is an individual or institutional/community/organizational activity. Taking part at an international conference is often an individual initiative, while taking part in a transnational educational programme or research project requires serious organizational background and coordination. It is worth distinguishing the quantitative and qualitative line of internationalization, where quantitative elements are best captured by the number of courses offered in foreign languages and the number of students participating in international mobility; and the quality elements, such as the mobility of staff or the internationalization of curricula, are those that directly affect the quality of education. In addition, external and internal internationalization is also distinguished by experts. Internal processes include developments that provide an international learning environment within the institution (internationalization of curricula, using international literature in foreign languages, internal knowledge sharing, etc.).

Our research design and the online institutional questionnaire was based on the results of the indicator project on internationalization (IMPI) led by NUFFIC. The researchers used mixed methodology (both qualitative and quantitative data). Among the various mixed methodological constructions, convergent parallel design (Creswell, Plano, \& Vicki, 2011), one of the best known and most widely used forms of the 1970s, has been applied. The essence of the process is that the researcher simultaneously and independently conducts quantitative and qualitative data collection and data analysis, and links the two methodological directions by the interpretation of the results. The coherent parallel structure aims at better understanding a given social phenomenon by using two approaches (Király, Dén-Nagy, Géring, \& Nagy, 2014). The research on which this paper is based relied on triangulation and supplementary features of the mixed 
methodology (Greene, Caracelli, \& Graham, 1989). By using methodological triangulation, it is possible to check whether the results achieved by the different methods point to one direction. The findings of online research conducted among university staff were compared with the deeper information obtained from the interviews and only those reinforcing each other were used in the analysis. Complementarity, i.e. using multiple methods helps get a better picture of the phenomenon (Nagy Hesse-Biber, 2010, Sursock, 2015). Although one can get a general picture via the analysis of administrative databases, the motives and attitudes behind the processes were highlighted primarily by the qualitative analysis and partly by the answers given to the open questions of the online survey conducted among staff and students (Table 1).

Due to the scope and limitations of our study, we cannot cover all areas of analysis. In this paper, we focus on the results of the online survey conducted among university lecturers, as well as covering the results of the student survey on certain topics. In Hungary, students are regularly surveyed by TEMPUS foundation, but a survey among lecturers is quite rare and unique. We primarily used the results of the interviews we conducted in several institutions and our deep qualitative research among the members and students of five university faculties: University of Szeged, Faculty of Education; University of Pécs, Faculty of Arts; Corvinus University, Faculty of Social Sciences; Budapest University of Technology, Faculty of Architecture; Eötvös Loránd University, Faculty of Social Sciences. We selected these universities as a result of their more advanced focus on internationalization and we conducted 4-5 interviews in every institution and faculty with key players in the field of internationalization. Our goal was to exhibit specific institutional patterns and solutions, which emerge from the national average.

\section{STUDENT MOBILITY}

In international comparison, the percentage of international students in Hungary is high in medical and agricultural education, whereas it is relatively low in natural and social sciences. The percentage of international students is higher than the OECD average, however; the majority of international students study in $\mathrm{Ba} / \mathrm{BSc}$ or MA/MSc courses, and relatively few of them participate in $\mathrm{PhD}$ programmes. Inward and outward mobility are well balanced: the ratio of outgoing students matches the ratio of incoming students (OECD, 2017a).

It is interesting that all over the world the rate of mobility in doctoral schools is higher than at the BA/MA level, but in Hungary, on the contrary, student mobility is lower in doctoral education. The pattern of student mobility is very similar to that of Germany (Fig. 1).

A dynamic increase in the ratio of students of foreign citizenship could be observed for the past ten years. Whereas 3.9 per cent of all students studying in Hungary were foreign citizens in 2006 , the ratio of foreign students was 6.1 per cent in 2011, and grew to a total of 9.6 per cent of all students in higher education. In ten years' time, the ratio of foreign students more than doubled in Hungarian higher education.

The background factors behind this development are twofold. On the one hand, the absolute number of students of foreign citizenship has grown by 70 per cent. On the other, however, the higher ratio of international students is also attributable to the fact that the number of domestic students dropped significantly (by more than one-third) during the same period. During the 10 years in question, the total number of students in Hungarian higher education dropped by 
Table 1. Instruments and data used in the research

\begin{tabular}{|c|c|c|c|}
\hline Instrument & $\begin{array}{c}\text { Target group/targeted } \\
\text { documents }\end{array}$ & Sample size & $\begin{array}{c}\text { Components of the } \\
\text { sample }\end{array}$ \\
\hline
\end{tabular}

Quantitative methods

1. Analysis of higher education registers

2. On-line data collection OctoberNovember, 2017

Qualitative method

3. Document analysis, literature study

4. Interviews with university and managers, international coordinators, interviews with domestic and international students
FIR (Higher Education Information System), DPR (Graduate Career Tracking System), TPF

(TEMPUS Public

Foundation) databases

Managers, international co-ordinators, faculty members in higher education institutions

Domestic and international students studying in a Hungarian higher education institution

Websites of HE institutions, strategic documents of $\mathrm{HE}$ institutions Managers, international co-ordinators, faculty members in $\mathrm{HE}$ institutions

2,739 individuals from 35 higher education institutions 5 individuals from
higher education institutions

Full scale

28 interviews (of which 11 heads of doctoral schools or vice deans)

Domestic and international students studying in Hungarian higher education institutions Hungarian and foreign doctoral students in Hungarian higher education
44 interviews (22 international and 22 domestic students)

34 persons (15 foreign students, 19 Hungarian students)
$45 \%$ in top management positions, $44 \%$ faculty members or department managers, $11 \%$ international coordinators $61 \%$ international students, 37\% domestic students, $2 \%$ crossborder Hungarian minority students

Corvinus University of Budapest, University of Technology and Economics, Eötvös Loránd University, Óbuda University, University of Pécs, University of Szeged, Central European University

Corvinus University of Budapest, University of Technology and Economics, Eötvös Loránd University, Óbuda University, 
Table 1. Continued

\begin{tabular}{|c|c|c|c|}
\hline Instrument & $\begin{array}{c}\text { Target group/targeted } \\
\text { documents }\end{array}$ & Sample size & $\begin{array}{l}\text { Components of the } \\
\text { sample }\end{array}$ \\
\hline $\begin{array}{l}\text { 5. Focus group } \\
\text { meetings, face-to-face } \\
\text { interviews and } \\
\text { interviews by } \\
\text { telephone }\end{array}$ & $\begin{array}{l}\text { Representatives of firms } \\
\text { and research institutes }\end{array}$ & $\begin{array}{c}\text { Two focus group } \\
\text { meetings, } 8 \text { interviews }\end{array}$ & $\begin{array}{c}\text { Sopron Campus of } \\
\text { University of Western } \\
\text { Hungary, Moholy-Nagy } \\
\text { University of Art and } \\
\text { Design, University of } \\
\text { Pécs, } \\
\text { University of Szeged, } \\
\text { University of Debrecen, } \\
\text { Pázmány Péter Catholic } \\
\text { University } \\
\text { Hungarian Academy of } \\
\text { Sciences, } \\
\text { Centre for Social } \\
\text { Sciences, Eötvös Loránd } \\
\text { University, Corvinus } \\
\text { University of Budapest, } \\
\text { Hétfa Research Institute, } \\
\text { Budapest Institute, } \\
\text { Telecom and partners; } \\
\text { Bay Zoltán Nonprofit } \\
\text { Ltd. for Applied } \\
\text { Research, Graphisoft, } \\
\text { Gedeon Richter Plc., } \\
\text { Ericsson, Vodafone } \\
\text { Head-hunting firms: } \\
\text { Beck and Partners, } \\
\text { Aarenson, VPS Group } \\
\text { Kft., Tesk, Randstad }\end{array}$ \\
\hline
\end{tabular}

140,000 . The growth of the number of international students by 11,000 could not counterbalance this loss.

Using university registration data, statistical analysis was made of the internationalization of Hungarian higher education. (It should be observed that the official statistics currently available have limitations that do not allow to describe the state of internationalization of higher education in sufficient detail. It is not possible, for example, to fully distinguish the credit mobility from degree mobility or to detect practices leading to mixed cases of credit and degree mobility.) Four characteristically different groups of students were distinguished, these are as follows:

Group 1: Degree mobility students (except for medical students)

Group 2: Degree mobility students studying medicine

Group 3: Credit mobility students in BA/BSc and MA/MSc courses

Group 4: Cross-border Hungarian minority students (for explanation see textbox below) 


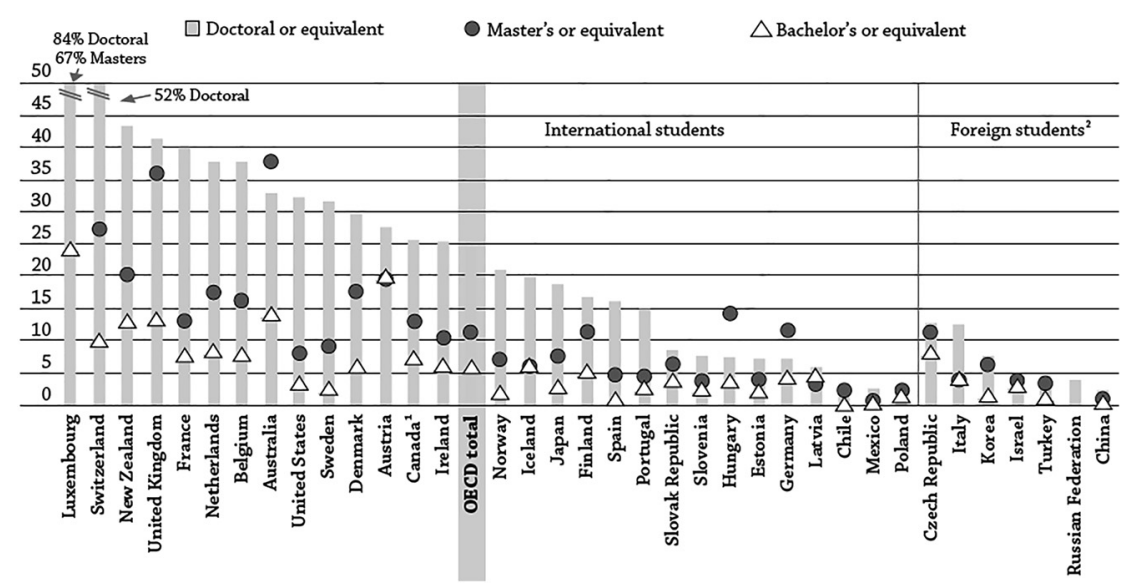

Fig. 1. International student mobility, 2012/13 (\%), Source: OECD (2015), Chart C4.2

The peace treaty closing the First World War attached two thirds of Hungary's territory to the surrounding countries. As a result, a significant number of Hungarians are trapped - as a minority - outside the mainland. According to the latest censuses, their number is still 2.5 million (25\% of the mainland population). Most of them live in Transylvania (Romania), in Highland (Slovakia), in Vojvodina (Serbia), and in Transcarpathia (Ukraine). To provide services in the mother tongue to Hungarians living in the neighbouring countries has been a key aspect of the governments of Hungary in the past hundred years. In the area of higher education, this policy is implemented partly through the export of provisions of the Hungarian higher education institutions to the neighbouring territories, and partly through the promotion of participation of Hungarian minority students in the higher education of mainland Hungary. Many Hungarian professors are still deeply dedicated and committed in teaching Hungarian minority students either in their own home institutions in Hungary, or in the few universities operating in the minority areas, where the language of instruction is Hungarian.

Among international students enrolled in degree courses, the most dynamic increase in numbers were found in Group 1, where Chinese students constitute the largest group with over 1,000 students. An increase in student numbers can also be seen in Group 2 (medical students), though the growth rate is slowing down. In this group German students represent the largest nationality.

On the other hand, there is a marked decrease in the number of cross-border Hungarian students. In total, the number of cross-border Hungarian students dropped by 1,700 in the past five years (Fig. 2). International students with a Hungarian background mostly chose to study at universities near the Hungarian border, such as University of Szeged, University of Debrecen, Széchenyi István University (Győr), Szent István University (Gödöllö), but a significant number of students study in Budapest at universities with great tradition such as Eötvös Loránd University or Budapest University of Technology and Economics (BME). Interestingly, University of Pécs did not seem so attractive for cross-border Hungarian students.

Credit mobility students arrive in Hungary with very different study backgrounds. It is often problematic to fit their studies in the structure and content of the university's course 


\section{Changes in the numbers of international students (degree mobility students) 2006-2017}

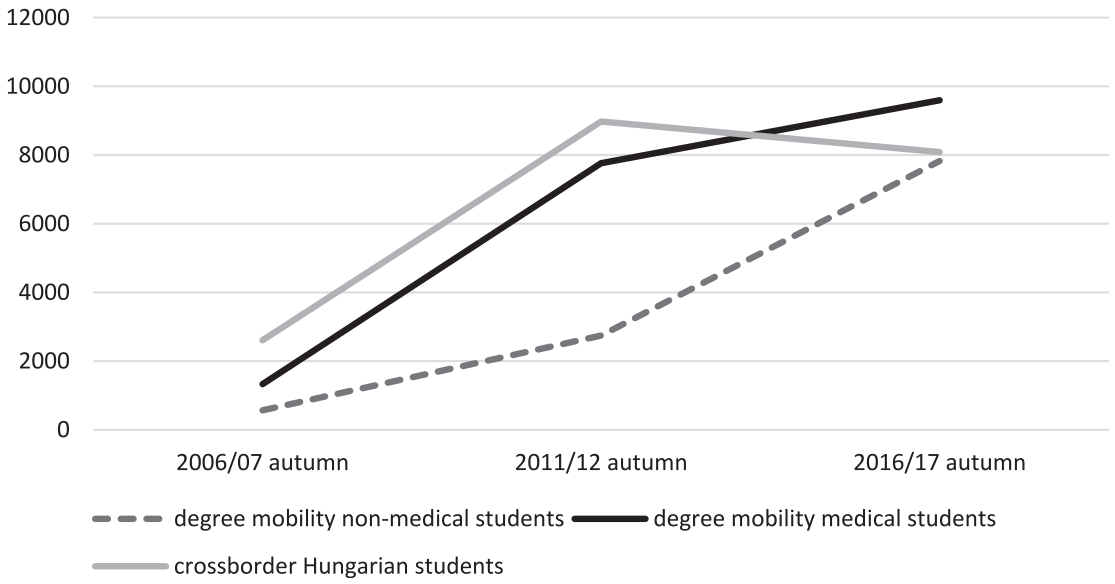

Fig. 2. Changes in the numbers of international students in Hungary between 2006 and 2017 (Source: FIR ad hoc query; CSO on-line published statistics in education, Students, graduates in higher education)

programme. At the same time, this occasionally inspires the teaching staff to find new solutions for the problem. One of our respondents reported that Erasmus+ students are given an innovative project-based course package at the Faculty of Architecture of Budapest University of Technology and Economics. Admittedly, the aim of developing this course package was meant to offer this course eventually also to Hungarian students. It seems, however, that such innovations are difficult to carry through in the given institutional culture and in the existing bureaucratic framework of regulation.

For Hungarian students, the lack of non-recognition of the Erasmus + semester often means a delay in graduation. Furthermore, the Erasmus + grant covers only a small part of the costs of studying abroad for the student. On top of this, many Erasmus + programmes are not equally accessible for Hungarian students. Among others, this may be one reason why universities and their faculties differ in the extent to which they can use the Erasmus+ programme for students. As far as staff mobility is concerned, institutions can use the opportunities of the Erasmus+ programme much better. The places available are usually filled.

The majority of our respondents who are teaching staff members report that their institution ascribes credits to studies abroad. Fifteen per cent say that foreign credits are rarely acknowledged in their institution, and 20 per cent say they are in some cases and not in others. Nonrecognition of credits obtained abroad is a persistent problem as was shown by a study of Tempus Public Foundation several years ago (Tempus Public Foundation, 2015). As transpires from the interviews, it still exists.

The Eurostudent VI research based on student responses produced a rather disappointing result about Hungarian higher educational institutions' recognition of credits, especially compared to other European countries (Fig. 3). These results are essentially the same as the findings of similar studies conducted in the past decade. It seems the Hungarian credit 


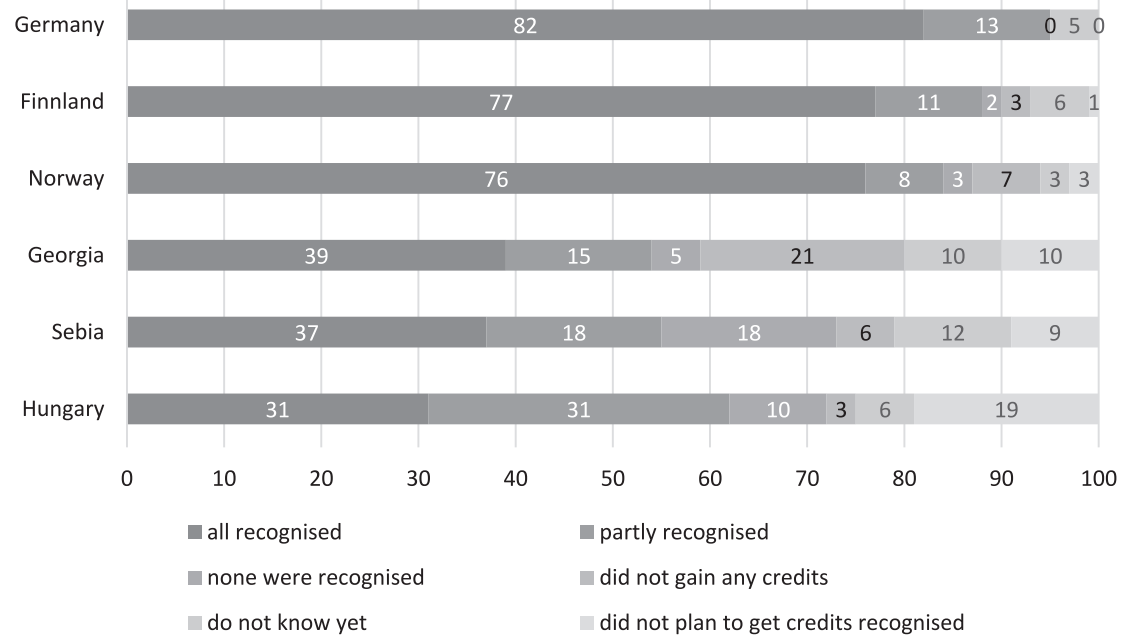

Fig. 3. Way and extent of recognition of credits gained with study-related activity abroad. (\%), Source: EUROSTUDENT (2018) 1.7; Top and bottom three on the list of result of European countries

recognition practice has been stuck at a low level. This can be for a number of direct and indirect reasons, the exploration of which is beyond the scope of this study. However, one thing should be pointed out: the low level of full or partial recognition of credits not only limits mobility but can also set back the effectiveness of institutional training and the efficiency of students' learning.

\section{THE DIFFERENT PATTERNS OF INTERNATIONALIZATION OF BACHELOR, MASTER AND DOCTORAL EDUCATION}

One of the most striking results of the two research projects is the sharp differences in the opinions of staff on the purpose of internationalization and the international activities characteristic of undergraduate and master's degree programmes or of the doctoral schools.

Managers and the academic staff were asked a question about the most important strategic goals of internationalization in their higher education institution as a whole. Mobility appeared to be among the most important strategic goals for 38 per cent of the 205 respondents. The second most often mentioned answer was participation in joint projects, international conferences and research (26 per cent). International visibility, improvement of academic quality, and broadening the offer of foreign language programmes were the third and fourth most frequent answers (mentioned by 15 and 13 per cent of the respondents respectively). The views of those who are engaged in doctoral programmes significantly differed in one thing from those who are not: namely, they rarely mentioned mobility as a goal of internationalization. This difference was also confirmed by the analysis of the responses to questions asking about the importance of different possible internationalization goals and by the interviews with academic staff members (Fig. 4). 


\section{Views on the strategic goals of \\ internationalization ( $\mathrm{N}=146$, of which 18 heads of \\ doctoral school or programme)}

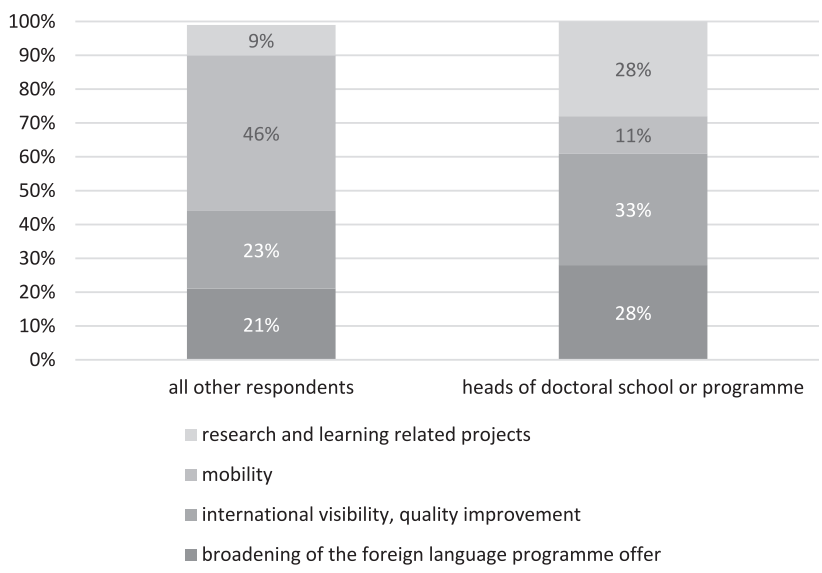

Fig. 4. Percentages of staff views on the most important institutional goals of the internationalization strategy ( $N=146$, of which 18 heads of doctoral school or programme)

Mobility goals were most frequently emphasized by top and middle-level managers and international coordinators. The importance of university revenues and the prestige of the institution were stressed most markedly by members of the academic staff. Middle managers appear to have the most balanced approach to internationalization: besides the goals mentioned above, they also stressed the importance of access to international publications and conferences. Interestingly, heads of doctoral schools and programmes viewed these goals somewhat differently.

To the question whether their institution (faculty, department or doctoral school) has an internationalization strategy, 68 per cent of staff members of doctoral schools reported that they had one, whereas the rate was 55 per cent (not a statistically significant difference) among respondents who were not involved in doctoral education. On the other hand, 43 per cent of the staff members of doctoral schools reported that the school had an internationally accredited doctoral programme, which term was used as a main sign for internationalization. Regarding the responsibility for their internationalization strategy, 38 per cent mentioned the head of the doctoral school, but an equal proportion of the respondents meant that there was no designated person for the strategy in their doctoral school. The dean and the director of international affairs were mentioned by one respondent each as the person responsible for the internationalization strategy. The responses suggest that the doctoral school staff interpret internationalization primarily at the school's level where collective responsibility is often substituted by individual responsibilities for internationalization.

On the whole, doctoral schools have the same kind of international activities as other parts of the university. In certain areas, however, they work more actively towards internationalization than, for example, their colleagues engaged in undergraduate or graduate (master's) education. Such areas are, among others, the internationalization of content, search for research partners abroad, support of student mobility, etc. Yet, doctoral schools are none the less active with regard to the internationalization of the academic staff or transnational education. Interestingly, 
international education in a virtual space, employing international professors, or activities such as those of student or teacher ambassadors are not parts of their toolkit of internationalization.

On the other hand, doctoral schools are ahead of undergraduate and graduate education in internationalization of the learning environment within the institution. They use much more foreign literature, they build on the knowledge and experiences of their foreign students more often than their colleagues teaching undergraduate and graduate courses. They are also a lot more dissatisfied with the traditional content of teaching and the lack of international approach in content development than the rest of the academic staff. Their approach reflects awareness of international trends in postgraduate education and they are more sensitive to education quality and the effective use of internal capacities (Fig. 5).

\section{International activities where doctoral schools are significantly more active (\%)}

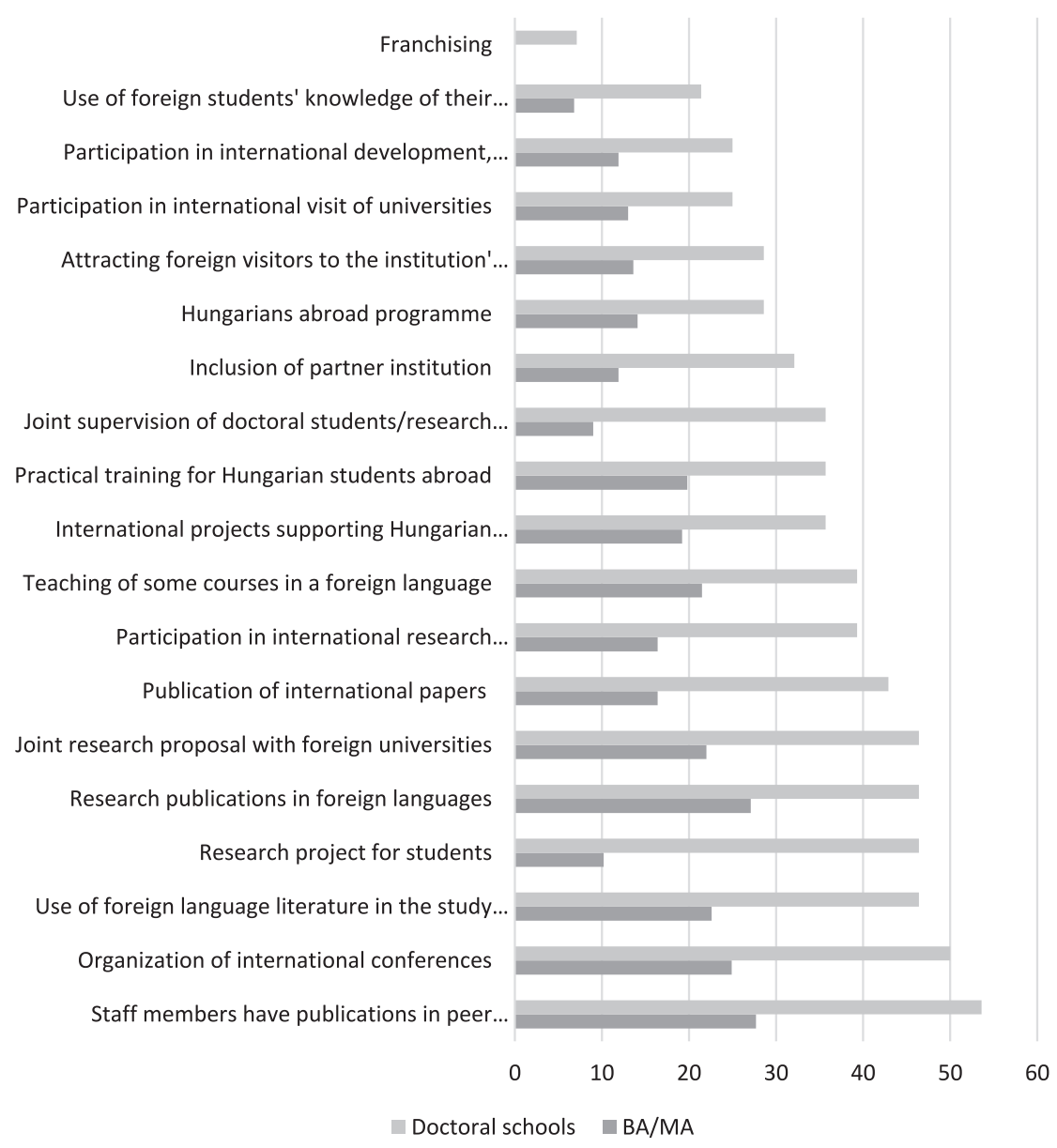

Fig. 5. International activities at the doctoral level and at bachelor's and master's level 
Regarding student mobility, Hungarian students who study abroad are typically selffinancing or study on special grants like a foreign or international scholarship. There are no mobility programmes attached to doctoral schools. However, doctoral schools support participation at international conferences and they do not make distinction between Hungarian and international students in this respect. Within their tight budget, doctoral schools try to ensure that each doctoral student participate at one major European conference. They make substantial efforts to find the means for supporting international publications but the resources available for this purpose are very limited.

\section{OBSTACLES TO INTERNATIONALIZATION}

Half of the respondents think that insufficient foreign language competence of students, lecturers and the administrative staff is the most important obstacle to internationalization in higher education. The second most frequent mention was shortage of funds. About one in four respondents mentioned structural problems and problems with human resources. This latter covers remarks concerning the fragmented nature of the organization, incompatibility of structure and content of the degree courses with international practice, unsatisfactory quality of human resources, and few international connections. Ten per cent of mentions are related to inadequate regulations, wrong approach by the management, overcomplicated processes in application for grants, and excessive bureaucracy (see Fig. 6).

In two items, there is significant difference in the responses of respondents in management position and members of the teaching staff. Managers see the lack of foreign language

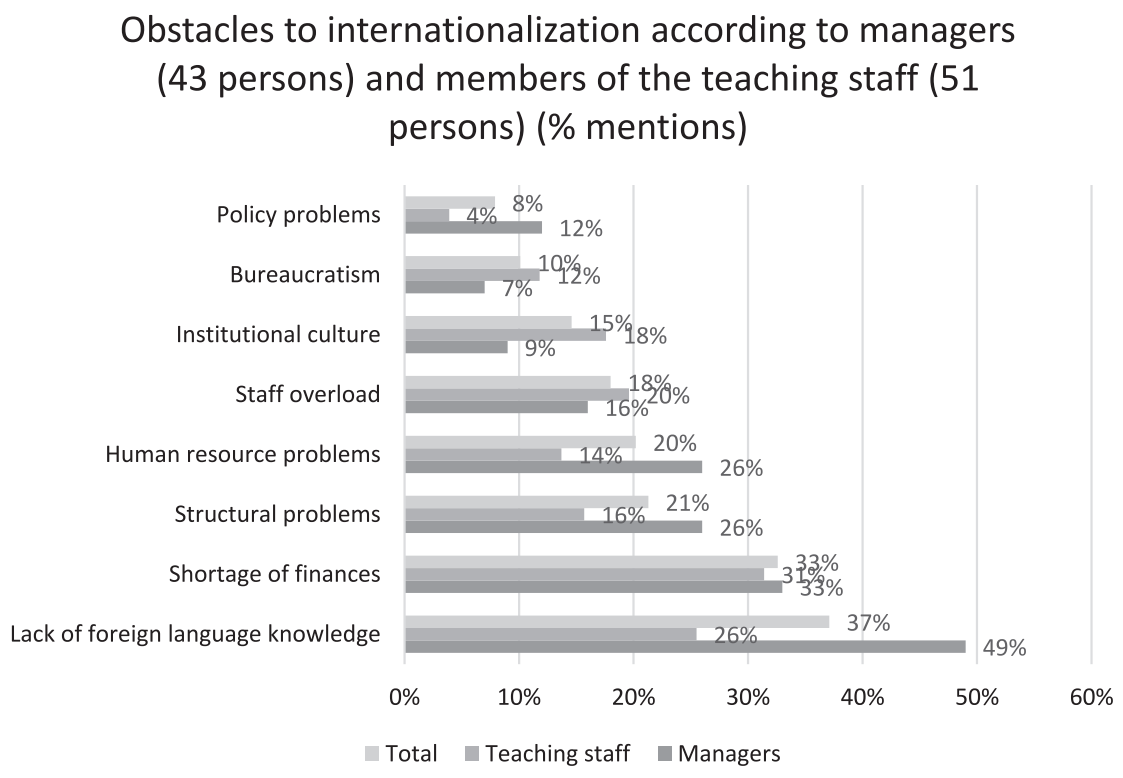

Fig. 6. Obstacles to internationalization according to managers (43 persons) and members of the teaching staff (51 persons) (\% mentions) 
competence and structural problems (fragmentation of leadership, incompetence, and incompatibility of content and structure of courses with international practices) as much more serious problems than members of the teaching staff do.

Heads of higher education institutions view that insufficient language competence is the greatest obstacle to internationalization, most of all at mobility. To the question about language learning possibilities in their institution, four per cent answered that there are no foreign language courses at all in their institution. 36 per cent replied that there are general language courses for students and 29 per cent reported that professional or technical language is taught in their institution. One fourth of staff members and department managers answered that students must finance their language learning themselves.

Of all students asked, the largest proportion reported that professional language courses were the opportunities to improve their foreign language competence, followed by the proportion of students reporting that there are general language courses available. Five per cent of $\mathrm{PhD}$ students and 10 per cent of undergraduates have not even heard of language learning possibilities at the university. Hungarian students of faculties of humanities, economics, and social sciences feel most that the university urges and encourages them to improve their foreign language competence, and students in teacher training find the least encouragement to develop foreign language skills.

One of the greatest problems of internationalization is that the institutional culture of Hungarian higher education is rather introverted. Reading foreign language literature is not much required in most Hungarian higher education courses, and the offer of foreign language courses is rather limited. Although there are good examples of higher education institutions organizing language courses from internal resources, this is not the general practice.

While most students report that they are given some obligatory readings in foreign languages, this is rare for the majority. Foreign language readings are most required at postgraduate level, less so in master's courses and it is least required in undergraduate courses. The majority of our respondents belonging to the teaching staff confirm that the list of obligatory readings contains few foreign language texts if any at all (see Fig. 7). 49 per cent of the respondents report that they sometimes use foreign language texts in their work with students, eight per cent report that they never do. Thirty-one per cent report that they use foreign language texts in several courses, but only 12 per cent seem to use foreign language texts almost all the time.

The idea that English should be used as the language of instruction at least in part of the courses is emerging in more and more institutions. Supporters argue that this could improve students' language skills, enhance communication and exchange of experiences between domestic and international students, and it would contribute to openness towards foreign students. However, capacity and tight budget as well as legal impediments are serious obstacles. The Higher Education Act states the preference of Hungarian as the language of instruction and, at the same time, the teaching staff are not encouraged to take on extra burden.

\section{HUNGARIAN HIGHER EDUCATION HAS REACHED A TURNING POINT}

Hungarian higher education has come to the point where, from a one-sided quantitative approach that focuses only on mobility, it should change into a quality dimension since professors are overloaded. The universities involved in internationalization should be a lot more 


\section{Amount of foreign language texts in the obligatory readings of courses in Hungarian}

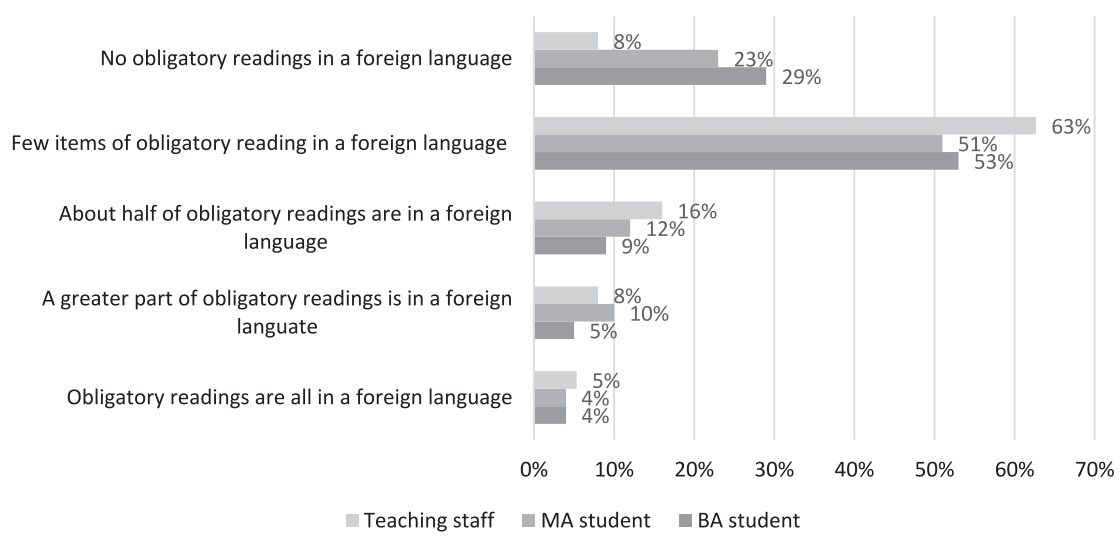

Fig. 7. Extent of use of foreign language texts and literature in Hungarian higher education courses reported by teachers $(N=75)$ and students (BA students $=329$, MA students $=99)$

innovative, i.e. not only attracting state-subsidized, but self-paying students, too, by offering them high-quality and creative education.

The quality of professors is the most important key to high quality higher education. One solution could be to employ well-known foreign professors, but this is hampered by several obstacles. The bureaucratic management process in the Hungarian higher education is not aligned with the expectations of scientific life and therefore often seems to be counter-productively rigid. Another limit to employment of foreign staff is the shortage of resources, so universities can invite guest professors only for a relatively short time, or they can afford them if they are on sabbatical and their salary is paid by their home university. Possible wage tensions also deter leaders of the university from employing foreign professors.

With regard to the future ideas of the university heads and academics interviewed, three approaches can be distinguished depending primarily on the degree of internationalization at a given institution. Those who are still at the beginning of the process understandably have the objective of expanding English language courses, increasing the number of English-speaking staff and the number of foreign students, as well as to increase bilateral contracts and participation in more professional forums. Institutions at higher levels of internationalization are already aiming at establishing double degree programmes or a bilingual university. This involves increasing the numbers of foreign teaching staff and promoting the institution's appearance in international networks.

Institutions at higher degree of mobility and of internationalization (where the real target is that the proportion of foreign students should reach 20-25 per cent) are focussing on content, quality and cultural elements. They are characterized by a student-centred approach and openness to other cultures, genuine curiosity about foreign experience, and reasonable international strategy. Here, not just the income generating import side of internationalization, but also the new knowledge-producing outcome side is important. 
From the five institutions (Corvinus University of Budapest, University of Technology and Economics, Eötvös Loránd University, University of Pécs, University of Szeged) in our qualitative research, University of Szeged (USz) stands out for internationalization, based on the following parameters:

- Highest rate of staff mobility according to official data and registers

- Highest number of international students in doctoral schools and the highest rate of those awarded doctoral degrees among the Hungarian higher education institutions

- Balanced portfolio (medical training, cross-border students, etc.)

- Student-centred approach (psychological assistance, active communication between students)

- An organization with a unified university brand

- Evidence based strategy of internationalization

- Adequate management and organizational culture

- Favourable location, good urban atmosphere, population, infrastructure

- Innovation (in joint training projects or the eDia development of the doctoral school of education)

\section{ORGANIZATIONAL CULTURE - WHERE UNIVERSITIES CAN DO A LOT ON THEIR OWN}

Teachers and managers who were interviewed, as well as those who filled out the online questionnaire emphasized that institutional culture and the inadequate interpretation of leadership have a hindering effect on the internationalization of higher education. Unity of action, level of internal cooperation and coordination are features determining how far an institution's organizational culture supports internationalization. It is no accident that the most frequent mentions of internationalization in our survey are publications, conferences and research. All are typically individual activities of academic staff members. The impact of such activities on the university largely depends on the organizational strength of the university's academic community. Unfortunately, excessive decentralization does not favour unity of action with respect to internationalization apart from the fact that its side effects are the waste of capacities and ineffective sharing of knowledge and information.

On the other hand, budget constraints and total lack of autonomy at lower levels of the organization (a feature of the chancellery system) do not promote internationalization either. Top managers often have to manoeuvre between the Scylla and Charybdis of university interest and individual ambitions without being able to attain synergy. Harmony can only be achieved in an institutional culture of trust and cooperation. The most successful institutions are the ones capable of establishing the delicate balance between the unity of action at the university level and academic autonomy at the faculty, and at the department and teaching staff level, which is a sine qua non of high quality education and research.

Students are also part of the institutional culture. Incidentally, wherever foreign and Hungarian students are taught together, the common experience of staff members is that Hungarian students are more restrained, less active, and less motivated than their international fellow students. If this attitude is the product of public education, it is no wonder that public education has a direct impact on the internationalization of higher education. 
Internationalization of higher education partly depends on how international students can be integrated into the professional and informal communities of Hungarian universities, how far they mix with Hungarian students. Our results show that a greater proportion of international students are open to get in contact with Hungarian students than vice versa and they are also willing to do something about. Hungarian students less frequently seek acquaintances among foreign students. Common course work, parties and sports events organized by the university are the typical scenes of mingling of the two groups, but a large proportion of both Hungarian and international students do not spend any time with members of the other group. According to the majority of respondents, the reason for this is not the lack of motivation but much rather the lack of opportunities. Both groups think that more social events should be organized by the university to help members of the two groups meet informally.

The lack of communication between domestic and foreign students is perceived by the leaders of the universities (perhaps with the exception of Szeged University, where students mingle easier). However, they think that this is a private affair and that this depends on the students themselves. It is clearly seen however, that the courseoffer is much different from what foreign students expect and the lack of common courses are mostly responsible for the insufficient opportunities for interaction of Hungarian and international students. Efforts on the part of staff members who wish to create a common sphere of interaction and communication for the two groups usually fade away either because of the problems of prevailing regulations or because of the lack of interest on the part of students.

\section{CONDITIONS FOR CONVERTING FROM A QUANTITATIVE PERSPECTIVE TO A QUALITATIVE APPROACH IN INTERNATIONALIZATION OF HEI}

Based on the findings, several phases of internationalization among Hungarian higher education institutions can be distinguished. In the case of the universities that are most advanced in this respect, uniform actions on institutional level and brand building are taking place, supported by thorough organizational changes. An independent institutional unit responsible for internationalization is one of the most typical forms of this. The organizational culture is essential in this process as the agent for internationalization must balance between the interests of individual excellence and that of the broader institutional community. Almost every Hungarian higher education institution has their internationalization strategy, and even though it is not always independent, it is usually an important part of institutional development plans. The interviewed staff members distinguish between mobility goals, research and prestige targets for internationalization purposes. It transpired that indirectly, according to the multidimensional analysis of their answers, for them prestige involves attracting foreign students rather than high-quality research. However, systematic monitoring of internationalization goals is not typical. If it is, then it is usually done for a less explicit, but crucial goal: to increase revenues.

Although the number of foreign students in Hungarian universities has increased dynamically in recent years, it has been unable to counterbalance the large drop in the number of Hungarian (including cross-border) students in the past decade. Hungarian universities are still invisible for the rest of the world. For the foreign students, the attractiveness of scholarships and Hungary (Budapest) is the decisive factor. Besides the lack of resources, the teachers and students surveyed say that the low level of language and communication skills of students and 
academics are still a very big barrier to internationalization. Perhaps this is the reason why there is no intensive knowledge sharing between foreign and domestic students in Hungary.

Due to the European structural funds and the Hungarian Stipendium Hungaricum scholarship programme, Hungarian higher education has seen a lot of developments in internationalization over the last decade in terms of expansion of courses offered in a foreign language and of international student mobility. At present, institutions that have developed in these areas are already struggling with capacity problems, and increasingly perceive that quantitative expansion needs to be replaced by a kind of qualitative change in their internationalization. Internationalization of doctoral education can be a key to quality, but serious challenges are experienced in this area. The rise of doctoral schools in social sciences in the international scene has been welcomed, but it is striking that doctoral schools of technology and natural sciences are lagging far behind. It seems that social sciences are more budget-sensitive and are more concerned with their survival, whereas in fields where the domestic industry acts as a customer (technology and engineering fields), there is less revenue constraint and thus the need for internationalization is weaker. Doctoral schools, however, perform better in internal internationalization than the lower levels of higher education. The internationalization of curricula, the use of international literature in courses and the sharing of foreign experience are more characteristic of the doctoral schools (compared to the bachelor and master education).

Both teachers and students - based on the experiences of the interviews - believe that on one hand Hungarian higher education is too subject-oriented and does not focus on practice, and on the other hand doctoral programmes are not sufficiently research-focused. The overall approach to teaching is traditional, often relying on lecture style teaching (OECD, 2017b, p. 53) Instead of a professor-centred approach, practice and research-centred student-friendly training would be needed, which would also attract more capable students. Based on the focus group discussions, this would also be demanded by innovative companies operating in Hungary. For them, partnership with higher education would be attractive if there were registered patents and innovations in higher education that could be efficiently exploited in production. The findings of the research indicate that deans and heads of departments and the heads of doctoral schools would welcome a qualitative development based on the institution's research and development activities, which seems to be in contrast to the state-administrative logic of the revenue-enhancing target represented primarily by the Chancellery.

Increasing staff mobility is considered to be one of the key elements of a qualitative leap by the respondents. To promote this, however, requires a different strategy than the existing strategy of enhancing mainly student mobility. Unlike student mobility, imports of foreign professors and longer stays of Hungarian academics at foreign universities do not generate income for the institute - on the contrary: they cost a lot (employment of a foreign professor directly, and the mobility of domestic faculty indirectly involve additional costs, since they require lighter teaching loads and more substitution capacity). For quality change, setting priorities and making them accepted within the organization is necessary, inter alia. However, the attitudes of departments and researchers affected by non-co-operative and individual strategies often hinder the development of an organizational culture that promotes quality development.

\section{INTERPRETATION OF THE RESULTS}

The internationalization of Hungarian higher education has reached the level where progress can be made only if the quantitative approach is replaced by a qualitative approach. An internal 
source of quality internationalization can be the internationalization of the curriculum, the widespread use of international literature in foreign languages and the effective sharing of the mobility experiences of students and trainers. In this field doctoral schools are ahead. Poor foreign language knowledge, lack of openness and inadequate communication skills are the main barriers of internal internationalization. The shortcomings here are rooted mostly in public education. Therefore, it seems that one of the keys to quality internationalization of higher education is proper public education providing students with proper language and soft skills (such as openness). For this reason, teacher training that can empower teachers to be open to the world and to have a good mastery of a foreign language would be an important step forward in the internationalization process of higher education.

Besides well prepared staff another key to quality internationalization is well prepared students entering higher education. It seems that the decreasing numbers of domestic and crossborder Hungarian students are not only a quantitative problem, but also a qualitative one. Foreign students lured by the incentives offered by the Hungarian policy of "Opening to the East" often lack the knowledge that is expected at a Hungarian university. But due to universities' financial interest, these students are not rejected but enrolled in so-called preparatory courses. It is a commonly held belief that foreign students participating in undergraduate and master's courses do not meet the entry requirements of Hungarian doctoral programmes, so there they are not admitted. This is also the reason why heads of doctoral schools consider quantitative mobility less important than their colleagues teaching at undergraduate and graduate levels of higher education. Doctoral schools are much more quality-responsive than lower levels of higher education, and mobility in its currently exiting forms does not appear to correlate with quality. Thus, in addition to the opening to the East, opening to the neighbouring countries and to domestic students should be strengthened and both Hungarian and crossborder students should also be attracted.

Chancellor is a new position at the universities in Hungary, founded by an amendment of the Law on higher education in 2014. Chancellor is the chief executive officer (CEO) of the university. The chancellor and the rector are twin-leaders, they exercise their power in a functional division: the rector is the leader of the academic issues (research and teaching) and employer of the academic staff, while the chancellor is the head of the legal and financial issues as well as the operation of the higher education institution; s/he is also the employer of the management staff. While the rector is elected by the Senate, which is the main decision-making body made up of mostly academic staff and students, the chancellor is appointed by the prime minister, and employed and directly controlled by the state minister responsible for higher education.

As mentioned above, one of the most important keys to external quality internationalization is highly qualified professors. Hungary is not doing well in staff mobility. Hungarian academics can typically take part only in short term mobility, since their substitution is difficult due to a lack of capacity of Hungarian institutions. In addition to the shortage of resources and capacities, an inadequate organizational culture and a centralized administrative regulatory framework that is not in harmony with the world of scientific research are also obstacles to employing foreign professors and to sending Hungarian staff abroad for longer periods.

Although the Chancellery system helps to keep the budget in hand, overloading capacities negatively affects quality. What is more, subject and theory-centred education with little practice and research (as university staff teach almost up to the limits of their capacity and research is usually undertaken in separate research groups funded by the Hungarian Academy of Sciences 
(HAS)) is not sufficiently attractive to young people. The financial logic of the chancellery, the administrative logic of education management often clashes with the logic of the scientific world, which makes it difficult for universities to employ foreign professors. For this reason, it would be useful to provide mobility opportunities for knowledge sharing to the administrative staff members of the chancellor department in order to make them better understand the medium they regulate. This is also a question of trust and culture. The regulation of higher education is now extremely bureaucratic, while there is no real feedback and correction. The restoration of university autonomy and the creation of a supportive control environment for research and development would be needed.

In the internationalization of Hungarian higher education, medical and health science education plays an important role, since one can find here the highest proportion of solvent foreign students for decades, but its added value compared to the whole of Hungarian higher education is relatively small. The staff teaching at medical universities has a very simple idea of internationalization, i.e. the main goal is to increase the numbers of international students who can afford to pay the tuition fee. However, internationalization defined by international student numbers has reached its ultimate limits in medical education; in this area expansion can be made only with quality loss or with a very large additional investment. Typically, foreign students are separated from Hungarians at medical universities, and once they obtain master's level they do not want to go on to pursue doctoral studies. Provision of high quality education in this field is more and more difficult due to the scarcity of hospital capacities. Although this was not investigated in our research, there may be a qualitative difference in the background of this kind of distinction between courses offered in Hungarian or in a foreign language whereby fee paying foreign students are provided with better quality training despite scarce capacities. This is exacerbated by the fact that in international comparison the rate of foreign students in medical higher education is high in Hungary, but the proportion of people employed in health care is much lower. The question arises whether the revenue growth at an institutional level is commensurate with the loss at a social level, as other countries investing less in training can offer higher wages and absorb fresh graduates. This disadvantageous trend may also be a problem at an EU level. It is a question whether medical education and employment have not reached the level where the optimum resource allocation would require European level intervention.

It is also important to mention that neither Hungarian public education, nor Hungarian higher education is pupil/student-centred. Lack of learner-centeredness is not only apparent in methods but also in the quantity and quality of services provided to students. As far as services for international students are concerned, although these are widening and improving, they focus merely on incoming mobility and revenue. Institutions are less sensitive to the problems of foreign students already studying here. The most critical point is access to residence halls, as students with scarce own resources lured by the "Eastern Opening" cannot afford expensive suburbs, especially in the capital. Existing capacities, however, are limited and the preference of Stipendium Hungaricum students may even put Hungarian students at a disadvantage. In this area both lecturer and student feedback were very critical. In the field of services offered to students, mentoring service has been improving and there are some universities offering psychological counselling to foreigners. The degree of student-centeredness also shows how sensitive an institution is to quality aspects. There are no organized forums for channelling student experiences into the organizational culture. It would be worthwhile to encourage the institutions to share their good practices in this field. The website of the institutions is also a good litmus 
paper for where the institution is in the process of quality internationalization. There are some examples of websites that are universally branded, well designed and student-friendly.

If the dimensions of analysis (internal-external and quantitative-qualitative) are interlaced, we actually see the four stages of internationalization, from the first box to the second and third to the fourth. It is clear that Hungarian higher education institutions are mostly in the quantitative dimension of internationalization. Examining these boxes separately, one can also make targeted suggestions on how to progress (Fig. 8).

1. Quantitative internal internationalization - Most universities in Hungary already have many lectures and courses as well as a few degree programmes offered in English. At the same time, there are institutions where it is not the case, either due to the nature of training (teacher training) or because the university is still very new and there has not been enough time to develop such courses. There are universities where no courses are offered in a foreign language at all, but still there are foreign students (music and fine arts). Another group of universities teach all the courses in English. At this level, another important aspect is the proportion of academics teaching in foreign languages. The fewer they are the greater their burdens and the more likely it is that the two groups of academics (those teaching in Hungarian and those in a foreign language) will be totally separated at staff level, thus reducing synergy at departmental level. Where all instructors are required to participate in both types of education (Corvinus University's doctoral school in social sciences), there is a more balanced burden on teachers and the synergies of two-language training can be exploited. This requires that teachers should be appropriately proficient in English. There are good institutional practices to improve this, where the university's language lab provides language learning opportunities for staff (Budapest University of Technology and Economics). It would be useful to add an explicit foreign language skill development dimension to staff mobility and to include courses such as effective speech, lecturing skills enhancement and creative writing in exchange/mobility programmes financed by the European funds in Hungary.

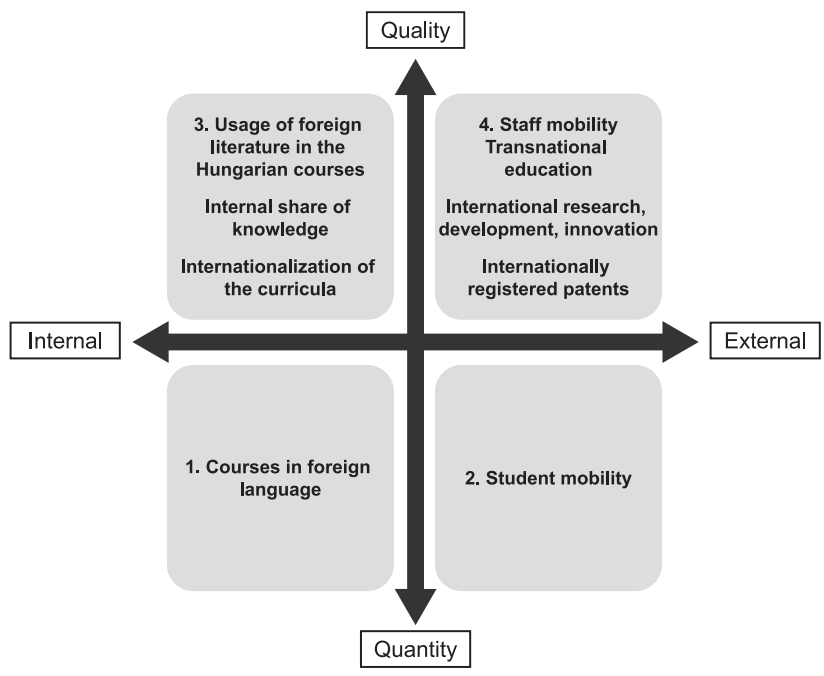

Fig. 8. A limited set of dimensions and the main phases of internationalization in higher education 
2. Quantitative external internationalization. As student mobility increases, there are institutions that have already reached or are close to the limit where the increase in the proportion of foreign students is no longer possible without deteriorating the level of quality. According to the interviews, foreign students, especially those with a scholarship of Stipendium Hungaricum, often do not beat the entry level, either in language skills or in preparedness, so institutions who do not dare to select students in order to receive state support for SH students, offer a preparatory year for them in many places. The increase in the number of foreign students in medical and health science education may not be worthwhile, and the balance between social and institutional returns may not be secured. In the spirit of the Eastern opening, the fact that the number of Hungarian (including the Hungarians beyond the borders) students is rapidly decreasing does not get enough attention, though they would guarantee a type of quality. Other source of quality could be the increased mobility of doctoral students, but doctoral schools should be made more interested in it. High-quality students can be lured only with high-quality staff (foreign professor, research-centred training) or with appropriate amount of scholarship.

3. Quality internal internationalization. The most important guarantee of internal quality internationalization is appropriate language proficiency and openness. Public education plays a crucial role in developing these competencies, and that is why teacher training is an important agent in the internationalization of higher education. Appropriate language and communication skills and openness of teachers can fundamentally influence the attitudes of future students and professors. Therefore, a much greater emphasis should be given to teaching foreign languages (in any case, English) in teacher training (according to the students who were interviewed, students in teacher training receive the least of foreign language learning opportunities).

4. Quality external internationalization. Staff mobility is a key to the external quality internationalization of higher education. This requires far more resources (time and money, as well as a shift in attitude in national education policy and in the organizations of HEIs). Additionally, the institutional system of R\&D in Hungary and the structure and volume of public spending allocated to it would be worth revising. The parallel institutional network of the HAS and universities, and favouring companies by the state (without adequate control and guarantee that public $R \& D$ money channelled to them reaches the universities) does not encourage Hungarian higher education processes that could promote qualitative internationalization.

According to the research findings, successful high quality internationalization of a higher education institution requires three basic things:

1. It is important for the university to be aware of its strengths and to build on existing traditions; this development should be organic, which enhances the organizational culture of the institution.

2. It is important to set priorities at an institutional level. It is worth investing in resources where the probability of quality development is greatest. This requires visionary leadership with appropriate competence to create an integrative organizational culture. At the same time, it is important to examine and harmonize these priorities. For example, at a national level, qualitative teacher training is an important key element of internationalization, which would surely be overcome by a narrower, voluntary and quantitative approach. Therefore it is important to manage the internationalization vision above the institutional level in order to 
allocate resources in an optimal way. Both national and institutional levels require real, reasonable and feasible strategies, which means that they are founded on the capabilities of the institution, and that the goals set are systematically monitored and adjusted in the light of feedback in a continuous fashion.

3. Currently, the financing and regulatory environment of higher education is not favourable for quality internationalization. Higher education must be removed from the state administration logic. More money needs to be invested, but more quality control is needed. An example of an Anglo-Saxon board type is a good example, where control is not on a day-today basis, but every control action has its consequences. The operation of the Hungarian university consistorium could be developed in such a direction.

Ethics: The study procedures were carried out in accordance with the Declaration of Helsinki. The TEMPUS foundation approved the study.

Funding sources: The research was carried out for the Tempus Public Foundation study of "Internationalization in Higher Education" within the framework of the EFOP-3.4.2-VEKOP15-2015-00001 project. It was funded by the European Union's Stuctural Fund.

Authors' contribution: All authors had full access to all data in the study and take responsibility for the integrity of the data and the accuracy of the data analysis. Judit Lannert: study concept and design, statistical analysis, interpretation. András Derényi.: study concept and design, literature review, study supervision.

Conflict of interest: The authors declare no conflict of interest.

\section{ACKNOWLEDGEMENTS}

The authors thank Szilvi Nyüsti for processing the FELVI data.

\section{ABOUT THE AUTHORS}

Judit Lannert is senior researcher at T-Tudok Knowledge Management and Educational Research Centre in Budapest. Her main field of research is public education, including student progression, career choice, pedagogical attitudes, relationship between student performance and pedagogical methods.

András Derényi at the time of writing this paper was a research fellow at the Hungarian Institute for Educational Research and Development in Budapest. Currently, he is a free-lance educationalist and consultant. His main field is higher education and lifelong learning.

\section{REFERENCES}

Brandenburg, U., \& Federkeil, G. (2007). How to measure internationality and internationalisation of higher education institutions? Indicators and key figures. CHE, Working paper, 2007, No. 92. 
Brandenburg, U., McCoshan, A., Bischof, L., Kreft, A., Storost, U., Leichsenring, H., (2013). Delivering education across borders in the European Union. Final Report. Luxembourg: CHEPS, European Union.

British Council (2018). International student mobility to 2027: Local investment, global outcomes. London: British Council.

Choudaha, R. \& De Witt, H. (2014). Challenges and opportunities for global student mobility in the future: A comparative and critical analysis. In B. Streitwieser (Ed.), Internationalisation of higher education and global mobility (pp. 19-33). Oxford: Symposium Books.

Creswell, J. W., Plano, C., \& Vicki, L. (2011). Designing and conducting mixed methods research. Thousand Oaks: Sage Publications.

Derényi, A. (2014). A felsőoktatás nemzetköziesítése: Globális pillanatkép [Internationalisation in higher education: A global snapshot]. In Zs. Veroszta (Ed.), A mozgás tere. A magyar felsőoktatás és a nemzetközi mobilitási folyamatok [Field of movement. Hungarian higher education and international mobility trends]. Budapest: Balassi Intézet, Campus Hungary.

EUROSTUDENT (2018). EUROSTUDENT VI. (2016-2018). Social and economic conditions of students life in Europe. Bielefeld: Bertlesmann Verlag.

Greene, J. C., Caracelli, V. J., \& Graham, W. F. (1989). Toward a conceptual framework for mixed-method evaluation designs. Educational Evaluation and Policy Analysis, 11(3, Autumn), 255-274.

Király, G., Dén-Nagy, I., Géring, Zs., \& Nagy, B. (2014). Kevert módszertani megközelítések. Elméleti módszertani alapok [Mixed Methods]. Kultúra és Közösség, 2, 95-104. https://www.researchgate.net/ publication/266262699_Kevert_modszertani_megkozelitesek_Elmeletek_es_modszertani_alapok.

Knight, J. (2012). Student mobility and Internationalization: Trends and tribulations. Research in International and Comparative Education, 7(1), 20-33.

Nagy Hesse-Biber, S. (2010). Mixed methods research: Merging theory with practice. New York: The Guilford Press.

OECD. (2015). Education at a glance 2015: OECD indicators. Paris: OECD Publishing. http://dx.doi.org/10. 1787/eag-2015-en.

OECD. (2017a). Education at a glance 2017: OECD indicators. Paris: OECD Publishing. http://dx.doi.org/ 10.1787/eag-2017-en.

OECD. (2017b). Supporting entrepreneurship and innovation in higher education in Hungary. Paris: OECD/ European Union, OECD Skills Studies.

Streitwieser, B. (2014). Internationalisation of higher education and global mobility. Oxford: Symposium Books.

Sursock, A. (2015). Trends 2015. Learning and teaching in European universities. Brussels: EUA.

Teichler, U., Ferencz, I., \& Wächter, B. (2011). Mapping mobility in European higher education, I-II., Bonn: DAAD.

Tempus Közalapítvány. (2015). Felsöoktatási nemzetköziesitési törekvések - A Tempus Közalapítvány által koordinált tevékenységek a Campus Hungary Programban 2012-2015. [Efforts at Internationalisation in Higher Education - Activities coordinated by Tempus Public Foundation in the context of Campus Hungary Programme, 2012-2015]. Budapest: TKA.

Open Access. This is an open-access article distributed under the terms of the Creative Commons Attribution-NonCommercial 4.0 International License (https://creativecommons.org/licenses/by-nc/4.0/), which permits unrestricted use, distribution, and reproduction in any medium for non-commercial purposes, provided the original author and source are credited, a link to the CC License is provided, and changes - if any - are indicated. 